\title{
Schumpeterian Entry: \\ Innovation, Exporting, and \\ Growth Aspirations \\ of Entrepreneurs
}

Entrepreneurship Theory and

\section{Saul Estrin' ${ }^{1}$, Julia Korosteleva ${ }^{2}$, and Tomasz Mickiewicz ${ }^{3}$ (i)}

\begin{abstract}
We posit that entrepreneurs who engage in strategic activities will have high growth aspirations. Our proposed mechanism is that strategic engagements, specifically product innovation, process innovation and internationalization, open entrepreneurial ventures to learning, and thereby greater growth opportunities. Furthermore, these learning effects are reinforced in research-intensive industrial environments. We apply multilevel random slope estimation for individuals from 74 countries, $200 \mathrm{I}-20 \mathrm{I}$, to derive results consistent with our hypotheses. The findings are robust to potential reverse causality between strategic behavior and growth aspirations, and to selection bias resulting from strategic engagements being only observed for actual entrepreneurs.
\end{abstract}

\section{Keywords}

innovation, exporting, entrepreneurship, growth aspirations, knowledge, global entrepreneurship monitor

In Schumpeter (1934 ) seminal work, innovation and successful entrepreneurship were viewed as being intimately connected. Yet in fact only a minority of entrepreneurs actually innovate, and new ventures differ widely in terms of their potential economic impact; their "quality" (Autio et al., 2014). In this article, we build on Schumpeter's intuition, postulating a mechanism to connect innovation with the aspirations of entrepreneurs and therefore potentially with economic impact. Specifically, we ask how innovation; internationalization seen as akin to innovation (Baumol, 2010); and innovation-supporting contexts may enhance entrepreneurial growth aspirations. In so doing, we address in greater depth research questions that have also been recently emphasized by Autio and Rannikko (2016).

Our theory therefore highlights the mechanism linking entrepreneurial growth aspirations to new venture strategies. Our measure of aspirations focuses on the growth intentions of

\footnotetext{
'London School of Economics, London, UK

${ }^{2}$ University College London, UK

${ }^{3}$ Aston University, Birmingham, $\mathrm{UK}^{3}$
}

\section{Corresponding Author:}

Saul Estrin, London School of Economics, Houghton Street, London, WC2A 2AE, UK.

Email: s.estrin@Ise.ac.uk 
entrepreneurs (Stam et al., 2012); given the difficulties in assessing performance at the early stages of new ventures, the literature has identified growth intentions or aspirations as a predictor of the economic potential of new ventures (Autio \& Rannikko, 2016; Kolvereid \& Isaksen, 2017; Mthanti \& Ojah, 2017). We draw on the expectancy theory perspective (Manolova et al., 2007) to argue that growth aspirations are affected by the emerging beliefs concerning the underlying potential of the venture (Capelleras et al., 2018; Levie \& Autio, 2013 ). These beliefs will be augmented by acquiring new, valuable, and nonredundant knowledge related to innovation and international orientation. Recent literature also prompts us to pay close attention to the context in which entrepreneurship occurs (Welter, 2011): we take on board the criticism of overindividualized approaches to innovation and entrepreneurship (Autio et al., 2014). We therefore contextualize entrepreneurship within the broader environment of knowledge creation, though we explore this at a sectoral level rather than in the more traditional geographical manner; here, a key element of our framework draws on the knowledge-spillover theory of entrepreneurship (Audretsch \& Keilbach, 2007).

Generation and acquisition of knowledge is risky but critical for new creative ventures to establish their competitive advantages in dynamic marketplaces (Alvarez \& Barney, 2007; Ketchen et al., 2007), and we expect these strategies to result in higher growth aspirations for the firm. This perspective points us to the mechanism whereby developing valuable opportunities (Alvarez \& Barney, 2007) leads entrepreneurs to greater growth aspirations for their new business (Estrin et al., 2013; Levie \& Autio, 2011). Thus, we argue that growth aspirations will be boosted by creative entrepreneurs forming opportunities by taking strategic actions (Alvarez \& Barney, 2007). Related to this, Bingham and Eisenhardt (2008) have developed a typology of strategic logics that underlie alternative pathways leading to competitive advantage. The strategic logic of opportunity, under which a competitive advantage stems from entrepreneurial action of capturing profitable market opportunities (Bingham \& Eisenhardt, 2008; Bingham et al., 2007), is particularly relevant here. Ambitious, entrepreneurial firms select the learning content and translate it into simple rules (heuristics) which guide the capture of opportunities and provide the firm with a series of temporary advantages (Bingham \& Eisenhardt, 2008; Bingham et al., 2007). To this analysis, we add the proposition that these processes also enhance entrepreneurial growth aspirations. Building on this, we focus on those aspiration-augmenting entrepreneurial activities associated with knowledge generation and acquisition via both product and process innovation (Kolvereid \& Isaksen, 2017), and via an international rather than a solely domestic market orientation (Capelleras et al., 2018). Further we analyze whether these strategies, jointly or separately, influence entrepreneurial growth aspirations. We further propose that such engagements will be mutually supportive (Bingham et al., 2007; Love \& Roper, 2015).

In addition, we follow the literature in acknowledging that firm strategies are not the only source of new venture opportunities; the context is also important (Audretsch \& Keilbach, 2007). This idea has been analyzed in terms of institutional arrangements at the national level (Autio \& Acs, 2010; Baumol et al., 2007; Estrin et al., 2013) or regional level (Audretsch \& Keilbach, 2008) but spillovers within an industry seems an equally important, but hitherto less explored, line of enquiry (Meyer \& Sinani, 2009). Thus, we propose that industry represents the appropriate level of analysis for contextual effects on the relationship between strategies and entrepreneurial aspirations. Therefore, we posit that a knowledge-intensive environment at the industrial level, conducive to opportunity formation, may especially influence growth aspirations of those founders already oriented towards knowledge acquisition and generation. We argue that the enhancement of the entrepreneur's growth aspirations through industry-level contextual knowledge intensity will be conditioned by his/her decision to engage in strategic activities which facilitate the generation and acquisition of knowledge about technologies, customers and markets. 
In our empirical counterpart, we follow the examples of Autio and Acs (2010), Estrin et al. (2013), Schøtt and Jensen (2016), and Capelleras et al. (2018) in applying multi-level modeling to a large cross-country cross-individual dataset of new firms over the period of 2001-2015. Our database is constructed from the Global Entrepreneurship Monitor (GEM) combined with information from a variety of country and industry-level sources. One major advantage of this dataset is that it includes both developed and developing economies; the omission of the latter has been recently identified as a major issue by Engelen et al. (2014). We also consider carefully two major econometric issues which may potentially affect our analysis. The first concerns the potential endogeneity between entrepreneurs' strategic behavior and growth aspirations, and the second is the selection bias, which may arise because the decisions to innovate, internationalize and grow a business are only observed for actual entrepreneurs. Here, we follow a call by Engelen et al. (2014) to take more seriously these biases in empirical research on innovation and entrepreneurship.

Our main contributions can be summarized as follows: we extend the understanding of the Schumpeterian entrepreneurial process by demonstrating the importance of creative entrepreneurs' strategic choices, which via knowledge generation and acquisition enhance the growth aspirations of new ventures. Building on expectancy theory (Manolova et al., 2007) we develop a theoretical framework linking entrepreneurs' growth aspirations with their strategic orientations towards innovation and internationalization, as well as with the opportunity context provided by a knowledge-intensive industrial environment. We argue that the benefits entrepreneurs derive from exposure to knowledge-intensive industrial contexts mainly accrue to product innovators, process innovators, and entrepreneurs engaged in the early-stage internationalization process; such entrepreneurs benefit more at relatively higher levels of R\&D intensity in their industry. More generally, this study bridges the gap between the innovation, strategic management, and entrepreneurship literatures, by articulating the path from entrepreneurs' strategic choices to their aspirations at the early stage of their venture's life.

We will next discuss our theoretical framework and motivate our hypotheses. A section on data and methods will follow, after which, we will present our empirical results. In the last two sections, we discuss the results and then offer our conclusions.

\section{Theoretical Framework and Hypotheses}

The causal mechanisms we postulate act through both single and multi-level effects. Our framework identifies three levels of analysis: the micro level (level 1) related to entrepreneurs, their strategic behavior, and aspirations related to their new venture; the industry level (level 2) related to the knowledge spillover context; and the country level (level 3). We will start with the micro level.

\section{Ambitious Entrepreneurship: The Theory Perspective}

We follow Stam et al. (2012) in suggesting that the term "entrepreneur" conflates two broad categories of individuals. In the first are those who are effectively self-employed, generating jobs primarily for themselves; here, Stam et al. (2012) applies the label of "marginal entrepreneurship". The second are termed "ambitious entrepreneurs" (ibid.). They are the ones who, at the moment of venture creation, aspire to create large scale businesses that could impact the growth path of their local region or even the national economy (Colombelli et al., 2016). Hurst and Pugsley (2011) identify this distinction empirically; thus, they point out that when new start-ups were asked about their growth ambitions, $75 \%$ of respondents stated that "I want a size I can manage myself or with a few key employees" (2011, p. 96). New ventures that do not have an 
ambition to grow will not do so, as the ambition itself is a necessary condition for growth (Stam et al., 2012). This contrasts sharply with entrepreneurial firms whose owners have the ambition to create high impact new ventures, with objectives sometimes stated in terms of earning millions or even billions of dollars.

Among those who aspire to grow may be entrepreneurs who anticipate opportunities arising from market imperfections that is: arbitrageurs (Kirzner, 1973). In this work, however, we focus on individuals whose focus is venture growth by exploiting opportunities created by the process of learning through trial and error involved in both bringing to market new products and learning from new markets, which provide sustainable competitive advantage (Alvarez \& Barney, 2007). We posit, that there is a distinctive route from acquisition and generation of new knowledge (both by innovation and internationalization) to the growth aspirations of entrepreneurs. Those who follow this route we would label Schumpeterian entrepreneurs (Schumpeter, 1934); see also: Stam et al., 2012; Stam, 2013).

Explaining this from the perspective of expectancy theory, the behavior of individuals derives from their beliefs that their efforts will result in successful performance. This is based on three relationships, namely: (a) expectancy; (b) instrumentality, and (c) valence (Manolova et al., 2007; Vroom, 1964). While "expectancy" refers to the belief that undertaking a certain effort would ensure certain level of performance, the "instrumentality" underlines the relationship between performance and the desired outcome, and "valence" signifies the satisfaction that the results may bring (Vroom, 1964). Expectancy theory has been adopted to study entrepreneurial behavior: linking individual beliefs in skills and abilities to entrepreneurial intentions (Wiklund et al., 2003); studying the relationship between growth aspirations and actual growth (Wiklund \& Shepherd, 2003); and exploring how entrepreneurs' aspirations are shaped by entrepreneurs' human capital and situational constraints such as network contacts (Manolova et al., 2007). Building upon this, we further propose the mechanism whereby entrepreneurs' growth aspirations are shaped by their strategic orientation of innovation and internationalization, jointly with the contextual environment.

\section{The Strategic Logic of Knowledge Generation and Acquisition}

There are a growing number of studies in entrepreneurship which highlight the central role of strategy for the performance of new ventures (Ketchen et al., 2007; Sirén et al., 2012). Given their limited stock of knowledge and their lack of market power, creative start-ups develop opportunities by strategic engagement in a trial and error learning process (Alvarez \& Barney, 2007), generating competitive advantages (Ketchen et al., 2007). According to Bingham et al. (2007), the strategic logic that drives entrepreneurs' decision to select certain processes (e.g., product or process innovation, exporting, acquisition etc.,) also enables them to identify, capture and exploit profitable opportunities. That in turn creates a sustainable performance advantage by capturing attractive but fast-moving opportunities sooner and more effectively than competitors. These activities constitute the strategies of entrepreneurial firms in dynamic markets (Bingham $\&$ Eisenhardt, 2008) and pursuing them has been compared to surfing: "performance comes from catching a great wave at the right time, even though the duration of the wave is likely to be a short and precarious 'edge of chaos' experience" (Bingham et al., 2011). By allowing entrepreneurs to accumulate experience and knowledge, these processes help to form dynamic capabilities and to facilitate further strategic learning (Sirén et al., 2012), thereby allowing them to translate the knowledge into heuristics for future decision-making (Bingham et al., 2007).

Building on this perspective, we focus on two elements of new venture strategy in the firms' early days: the decisions as to whether to generate new knowledge through innovation, which we classify in terms of (i) new products or (ii) new processes, and whether to seek knowledge 
acquisition internationally via (iii) producing, at least in part, for international customers. We propose that such choices represent emergent strategies that imply "tacit learning in path dependent process" by creative entrepreneurs (Alvarez \& Barney, 2007). This process enhances their set of opportunities and therefore affects their growth aspirations, consistent with expectancy theory discussed above.

An early strategic choice for an entrepreneur is whether to enter the market with a new product or service, or whether to adopt the preexisting supply model. In the latter case, the new venture will be largely replicating the technologies and products of existing firms, which will probably push entrepreneurs in the direction of cost-based strategies. Yet, entry based on new products or technologies is likely to imply greater uncertainty because the business model is not yet established and because new products may face initial consumer resistance; factors that may also restrict the availability of finance (Parker, 2018). However, the evidence suggests that if entrepreneurs do adopt a strategy to innovate, on average this will lead to a superior post-entry performance (Arrighetti \& Vivarelli, 1999); survival (Colombelli et al., 2016) and growth (Love \& Roper, 2015). At the same time, Kolvereid and Isaksen (2017) found innovation to be correlated positively with growth aspirations, though not with actual growth. The explanation of this apparent inconsistency is provided by Stam and Wennberg (2009): innovation is a high-risk high-gain strategy; it may not improve median growth, but it may have positive effect on the likelihood of emergence of "superstar" high growing firms.

More specifically, product innovation can allow the firm to improve its market position vis-àvis its rivals through product differentiation. Likewise, process innovation can boost a firms' productivity, profitability and employment growth (Becker \& Egger, 2013; Sakellaris, 2004). Arrighetti and Vivarelli (1999, p. 932) suggest that "since firms generally start very small /.../ they decide to hire new employees only in the case of very positive expectations regarding current and future incomes", and that in turn these expectations are positively affected by their ability to innovate. This is the core argument for us, which is further reinforced by Kolvereid and Isaksen's (2017) findings above. Similarly, McKelvie et al. (2017), drawing on the sample of the Swedish firms, show that it is particularly the engagement of firms in product innovation and in market information transmission that enhances the relationship in young firms between their growth orientation and the actual growth of their new venture.

Entrepreneurs face a further strategic choice, namely whether to limit their business initially to the domestic market or whether to internationalize from the outset. The benefits of internationalization arise in part because the potential market becomes far larger, permitting more rapid scaling up (Schwens et al., 2018). The decision of new ventures in expanding overseas is linked to new opportunities and the extension of the firm's business model to new contexts, yet in those, the firm may face a liability of foreignness (Wright et al., 2005). Such strategic moves allow start-ups to expand the diversity and novelty of their knowledge base and to reach beyond prevailing norms in thinking about business options (Capelleras et al., 2018). Thus, such firms may be able to appropriate local technologies that have been developed elsewhere (Mthanti \& Ojah, 2017) and implement new improvements while adapting their products to local conditions and needs (Baumol, 2010). The liability of foreignness implies that these firms need to be more efficient than their competitors in order to sell their products abroad, but exporting firms may also gain a sustained advantage from the knowledge generated by their international experiences. For example, they may learn from their foreign competitors, customers and suppliers how to raise productivity, cut costs and develop more attractive products. These types of inter-organizational learning derive from the firm's broader network of exchange partners (Bruneel et al., 2010).

Thus, we argue that a strategic logic of opportunity with respect to knowledge generation and acquisition via any or all of the strategies of product innovation, process innovation, and internationalization allows entrepreneurs to gain temporary competitive advantages (Wiggins 
\& Ruefli, 2005). Put another way, entrepreneurs generate quasi-rents stemming from the new technologies, new products, and access to more heterogeneous customer base, and these in turn affect their growth aspirations via the expectancy mechanism: these entrepreneurs become superior in their ability to identify, grasp, and synthesize potential strategic information, and that this positively affects their growth aspirations. This leads us to propose the following:

Hypothesis 1: The engagement of entrepreneurs in (a) product innovation, (b) process innovation, and (c) internationalization will positively influence their growth aspirations.

\section{Schumpeterian Entrepreneurship in Knowledge-Intensive Contexts}

We next consider how a new firm's growth aspirations may be affected by operating in a knowledge-rich business environment. In R\&D-rich environments, there are typically significant gains from cooperation (Baumol, 2010). Furthermore, environments dense in R\&D imply competitive pricing of technology and of innovation transfers; that benefits new innovative entrants in particular (Ibid.). Innovators-entrepreneurs may not be efficient producers initially, at least until they have fully scaled up, and therefore dense markets, where they can "sell licences to large firms that are in a position to undertake such activities" (Ibid.: 108), entail performanceenhancing opportunities.

Furthermore, knowledge and ideas for new ventures often originate from entrepreneurs interacting with other economic agents engaged in R\&D activities (Stam \& Wennberg, 2009). In knowledge-intense environments, interactions lead to entrepreneurial opportunities via knowledge spillovers (Audretsch \& Keilbach, 2007, 2008) with alternative formulations of new ideas or processes being combined and recombined in the search for sustainable competitive advantage. Taken together, knowledge spillovers go some way to explain the success of new ventures (Agarwal et al., 2007).

We propose that knowledge-intensity should be considered not only with respect to geographic location, as is the standard approach in the literature, but also concerning the industry in which the entrepreneur is located (Audretsch, 1995). Thus, not only are knowledge spillovers localized but that they are also heterogeneous across industries. New ventures can benefit disproportionately from knowledge spillovers (Audretsch \& Keilbach, 2007, 2008), and the impact is greater for knowledge-intensive industries at earlier stages of their life cycle (Audretsch, 1995). This implies that knowledge spillovers should be treated as industry—as well as geographically specific. Hence, the Marshall-Arrow-Romer model (Glaeser et al., 1992) focuses on localized knowledge spillovers between firms in a given industry. The assumption is that knowledge externalities exist predominantly for firms within the same industry, and therefore that knowledge spillovers across industries are less important. This leads us to specify knowledge spillovers in terms of both industry and country.

Hence, building upon the knowledge spillover theory of entrepreneurship (Audretsch \& Keilbach, 2007, 2008; Agarwal et al., 2007), we posit that the generation of knowledge in industry-country groupings provides an important source of entrepreneurial opportunities, which is likely to enhance entrepreneurial growth aspirations. This argument underlies our second hypothesis:

Hypothesis 2: Knowledge intensity in a particular sector in a country has a positive effect on the entrepreneur's growth aspirations. 
We have argued that the entrepreneurs' strategic orientation towards innovation and internationalization as well as the knowledge intensity of industry-country groups will both have a positive effect on entrepreneurial growth aspirations. We further propose that these factors will be mutually reinforcing.

First, in knowledge-intensive environments, not all entrepreneurs benefit equally. We propose that opportunities within knowledge-rich contexts are likely to be seized upon mainly by entrepreneurs who pursue (innovation and internationalization) strategies of knowledge generation and acquisition from the start of their business operation. Their enhanced acquisition of knowledge from the research rich environments will make aspiring to growth more likely. This is because strategically driven entrepreneurs exhibit a greater ability to grasp new opportunities that emerge within knowledge-intensive environments. Thus, entrepreneurs making strategic choices to introduce product and process innovations or to internationalize will simultaneously benefit more from internalizing environmental business knowledge, further enhancing their growth aspirations.

Furthermore, benefits from dense markets for transfers of innovation and of research outcomes, based on competitive prices (Baumol, 2010), discussed above, accrue predominantly to most innovative ventures.

We therefore propose that both the knowledge intensity of the external industrial environment, and learning opportunities offered by exporting will reinforce the effects of innovation. Thus, we hypothesize a multilevel relationship such that:

Hypothesis 3: High knowledge intensity in a particular sector in a country positively moderates the relationship between entrepreneurs' (a) strategic engagement in product innovation, (b) process innovation, (c) internationalization, and their growth aspirations.

Overall, our hypotheses are summarized in Figure 1.

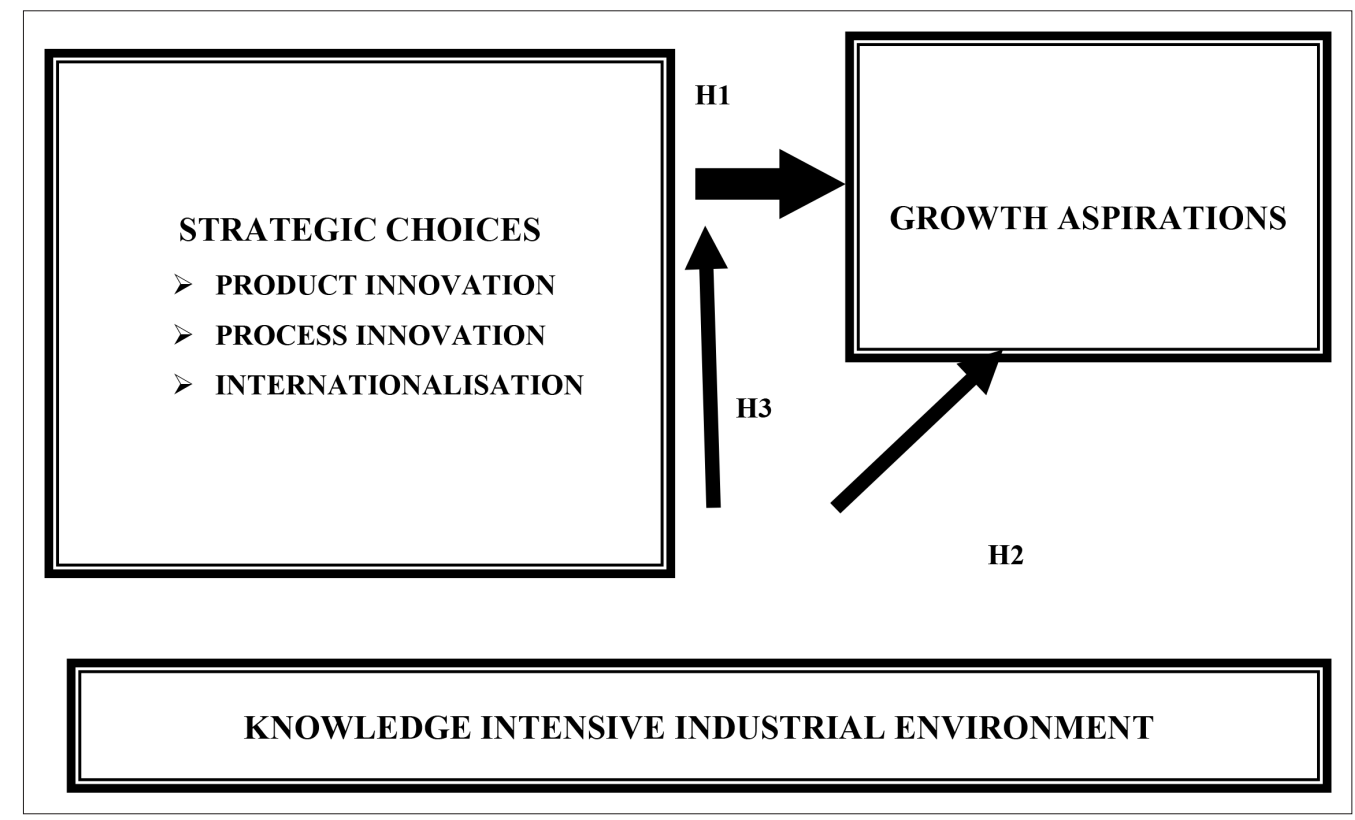

Figure I. Theoretical framework. 


\section{Data and Methodology}

\section{Data}

We construct a dataset to test our hypotheses by merging individual level data from the Global Entrepreneurship Monitor (GEM) with country-level R\&D and macroeconomic variables obtained from the Word Bank "World Development Indicators" dataset (WB WDI). The GEM data were collected through the adult population surveys in 2001-2015; they cover 74 countries in our sample. We draw only on the category of owners-managers of young firms (under 3.5 years old) to explore new venture growth aspirations. This is because the notion of strategic engagement at the heart of this article is more appropriately investigated within organizations which are beyond the nascent phase. For these young firms, innovation and internationalization are strategic actions that have already been implemented and determined.

\section{Dependent Variable}

Following our earlier discussion, we focus on entrepreneurial growth aspirations. We also note that prior research provides some evidence for a positive relationship between firm growth expectations and realized growth, and that low aspiration firms, which are the majority of all new ventures, rarely if ever grow (Kolvereid \& Isaksen, 2017; McKelvie et al., 2017; Wiklund \& Shepherd, 2003; for further overview: see Stam et al., 2012).

The dependent variable in our model is therefore entrepreneurial growth aspirations, measured by the growth in employment predicted by owner-managers of young firms. It represents the expected size of newly established ventures over a 5-year horizon, capturing ambitious entrepreneurship (McKelvie et al., 2017). It is calculated as the logarithmic difference of the current and expected levels of employment 5 years hence (Stam et al., 2012). ${ }^{1}$

\section{Independent Variables at the Individual and Country Level Related to Our Hypotheses}

Our hypotheses explore the impact on entrepreneurial growth aspirations of three elements of the young firm's strategies, namely: product innovation, process innovation, and internationalization. We measure the first two by using two variables related to product- and process innovation, as in Schøtt and Jensen (2016). Thus, an 'innovative product' (InnovP) in our dataset is drawn from the GEM question about whether "all, some, or none of your potential customers consider this product or service new and unfamiliar"; a dummy variable that takes the value of unity when all customers see the product as new. In turn, innovative processes, which for notational convenience we label "innovative technology" (InnovT) are captured through the question whether "the technologies or procedures required for producing this product or service have been available for less than a year, or between one to five years, or longer than five years". The variable takes the value of unity if "technology is within less than one year old"; zero otherwise.

To indicate whether the entrepreneur is following a strategy of internationalization, we use a variable denoting the "Internationalization" of young firms, as in Capelleras et al. (2018). This is scored as a continuous variable originally ranging from " 1 ", denoting that "more than $90 \%$ of customers normally live outside the country", to "7" - "none" of them. We reverse the scale of the original GEM variable for easier interpretation, with 1 now denoting no internationalization and 7 indicating the highest level of export intensity. We further transform this ordinal scale into a continuous one, taking the middle points of the respective range for ordinal categories: $1=0$; $2=5.5(<10 \%$ customers $) ; 3=18(>10 \%) ; 4=38(>25 \%) ; 5=63(>50 \%) ; 6=83(>75 \%) ; 7=$ $95.5(>90 \%$ customers living abroad $) .^{2}$ 
Moving to the industry level (2), we follow the knowledge-spillover entrepreneurship literature (Audretsch \& Keilbach, 2007) in testing Hypotheses 2, 3a-3c by measuring innovation and knowledge intensity of the start-up meso-environment through industry-level R\&D intensity. This is measured as the ratio of R\&D to value added within an industry, using an OECD taxonomy of economic activities (International Standard Industrial Classification Revision 4, ISIC 2-digit) (Galindo-Rueda \& Verger, 2016). ${ }^{3}$

\section{Control Variables}

We draw on the literature to specify a number of control variables both at the country and the individual levels. At the country level, the literature stresses the key role of the level of development, proxied here by per capita (pc) GDP at purchasing power parity (ppp). It has been established that entrepreneurial activity of all types is closely correlated with GDP per capita (for overview, see Estrin et al., 2019). We follow Estrin et al. (2013) in replacing per capita GDP ( $L n G D P p c \_p p p$ ) by dummy variables representing the five quintiles of its distribution (iq1-5). This helps to address a multicollinearity problem in relation to our instrumental variables that we discuss later on; the instruments - outgroup trust, and country-level R\&D are correlated with GDP pc ppp if the latter is entered as a continuous variable. Even if we are losing some information, though not too much, from the use of quintile dummies, the specification is quite flexible towards potential nonlinearities. We also control for the annual growth rate of GDP ( $l_{-}$ GDPgrowth) to reflect cyclical economic performance, expecting that entrepreneurs are less likely to launch ambitious projects in a recession (Koellinger \& Roy Thurik, 2012). We control for size of the national market using population size data, 1-year lagged and taken in logarithmic form ( $l$ LnPop_size $){ }^{4}$ We also include the density of established innovative businesses, expecting this to be negatively related to entrepreneurial growth aspirations because of competition. The innovation density measures are constructed as industry-country-year aggregates of respective innovation dummies for established businesses, separately for product and process (InnovDensP and InnovDensT).

At the individual level, we control for a variety of personal characteristics of entrepreneurs that have been found to influence the new venture growth (Parker, 2018). Previous research shows that entrepreneurs with higher educational attainment are more likely to direct their efforts towards high-growth activities (Autio, 2005), so we control for post-secondary education (EducPost). Middle-aged persons have also been found to be more likely to grow a business (Minniti et al., 2005), so we include the age of the entrepreneur (Age), using a quadratic form to allow for nonlinearity (Age_sq). We follow the literature (Estrin \& Mickiewicz, 2011; Minniti et al., 2005) in using dummy variables for gender (Male); for individual experience of being a business angel in the past 3 years (BusAngel); and for social networking utilizing a dummy variable with a value of unity denoting of whether the individual knows personally someone involved in a start-up (KnowsE). Last but not least, owning another existing business may also proxy for some learning effect embedded in earlier successful ventures; at the same time, it may raise the opportunity cost of a new involvement at a larger scale (Mickiewicz et al., 2017). Thus, we control for portfolio entrepreneurship (PortfolioE), introducing a dummy variable with " 1 " denoting entrepreneurs who are already owner-managers of established businesses (over 3.5 years old). Following Estrin et al. (2013), we also control for the current size of the firm (employment), expecting a higher initial level of employment to be negatively related to employment growth intentions (natural logarithm of current employment level, $\ln L$ ). For definitions of all variables, data sources and descriptive statistics, see Table 1 below. 


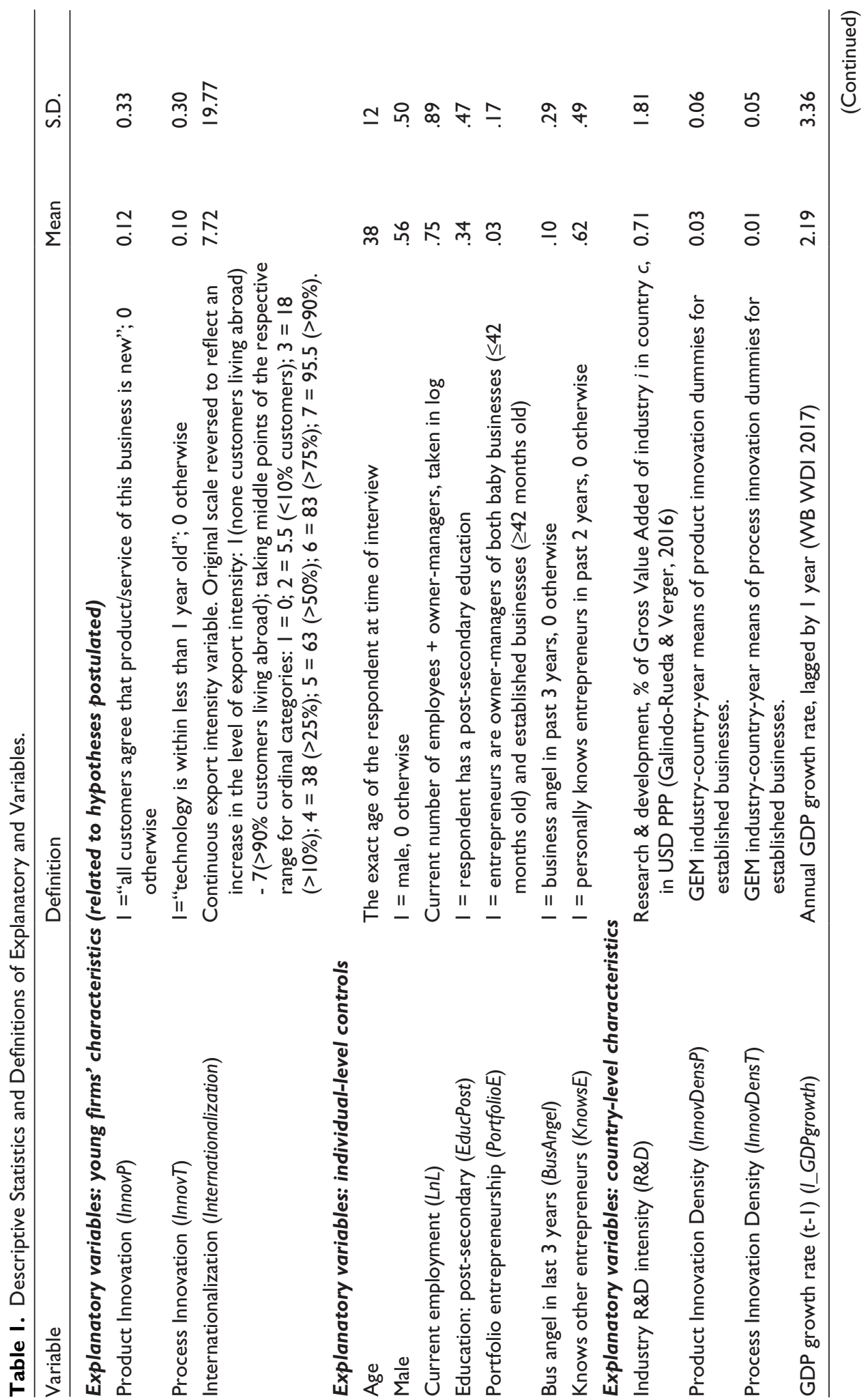




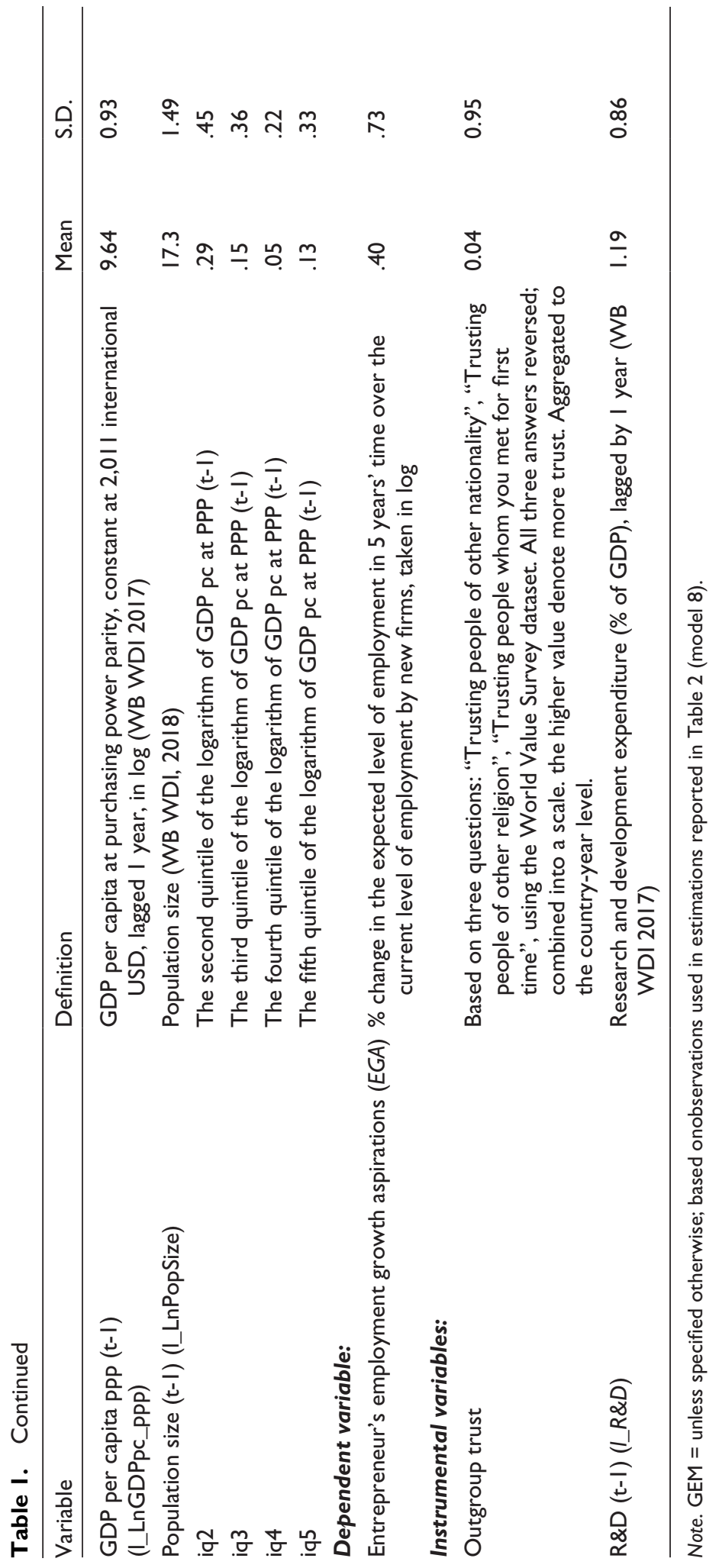




\section{Methodology: Multilevel Modeling}

We use multilevel modeling to address unobserved heterogeneity. Multilevel modeling takes account of the fact that the dataset has a hierarchical structure in which individuals represent level one, industry subsamples (ISIC 2-digit Revision 4) represent level two, and country-year subsamples represent level three. This allows us to control for clustering of the data within a 2-digit industry-country-year subsample. Failure to do this would lead to biased results (RabeHesketh et al., 2005).

To obtain our level two industry identification variable (TEA_ISIC2D), first of all, we had to harmonize GEM ISIC 4-digit variable (TEA_ISIC4D), using most recent ISIC Revision 4 classification. For this we followed the United Nations Rev 3.1 and Rev 4 correspondence tables ${ }^{5}$ to recode TEA_ISIC4D prior 2,010 (based on Revision 3.1) aligning it to TEA_ISIC4D Revision 4 classification. Second, we aggregated TEA_ISIC 4-digit variable to TEA_ISIC 2-digit variable, optimizing the number of observations within each 2-digit division.

We tested the appropriateness of employing Random Slope Model (RSM) vis-a-vis Random Intercept Model (RIM); the former allowing for both the intercept and slope of some variables to vary randomly across industry-country-year groups. More specifically, we tested whether the impact of entrepreneurs' product and process innovation engagement and export intensity is the same across industry-country-year groups by introducing random coefficients for these variables. The LR test statistic comparing RIM and RSM models was significant at the $1 \%$ level, justifying the use of RSM. This was further confirmed by the statistical significance of random slope coefficients for our individual-level innovation and exporting variables.

\section{Model Specifications}

As discussed above, we consider three strategic choices of entrepreneurs: two types of innovation, in product and process, and internationalization. We report results based on each in Table 2, Models 1, 3, 5; next, in a more demanding Model 7, we include all of them in a single equation. This enables us to test hypotheses $1 \mathrm{a}, 1 \mathrm{~b}$ and $1 \mathrm{c}$, and 2 . To test respectively Hypotheses $3 \mathrm{a}-\mathrm{c}$, we focus in Models 2, 4, and 6 on the two-way cross-level interaction results, exploring the conditional effect of knowledge-intensive environments on each of the three strategic choices singly at a time, and then jointly in Model 8.

To explore potential issues of multicollinearity, we followed Wooldridge (2015) in calculating variance inflation factors (VIF) for all our variables based on the full sample. We found no indication of multicollinearity problems with a mean VIF score being below the threshold of 10 consistently across all models (Table 2 below and Appendix Table A.II for these results; see also the correlation matrix, reported in Appendix Table A.I. In all models the mean VIF score is inflated by the age and age squared variables; as by the construction the two are highly correlated. Following Allison (2012) the inclusion of powers or products as a source of multicollinearity can safely be ignored.

Our baseline specification utilizing both innovation types (RSM, reported in Model 7, Table 2) is as follows: 
๔

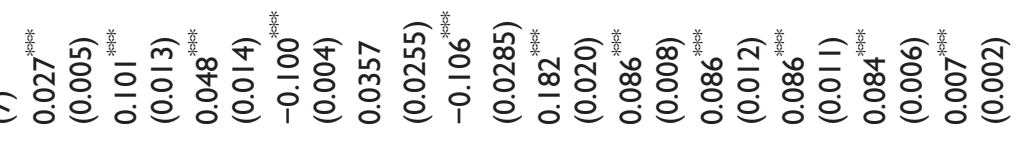

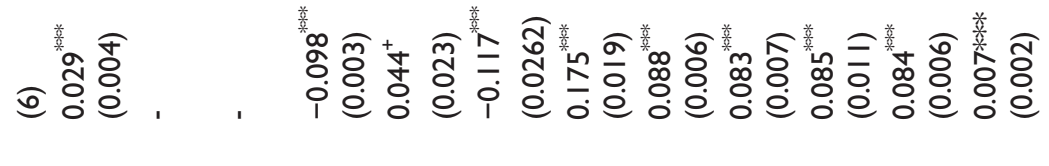

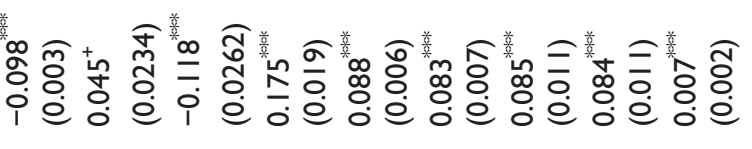

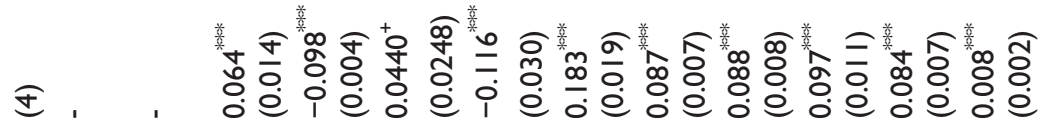

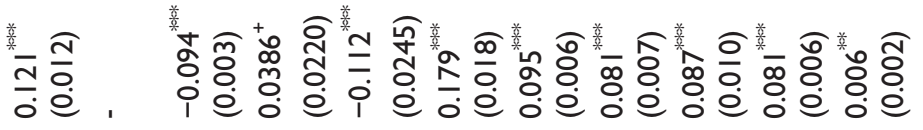

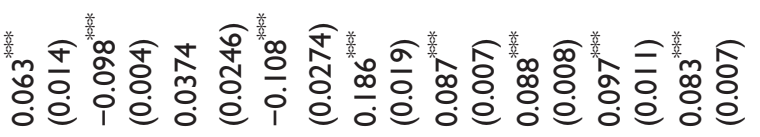




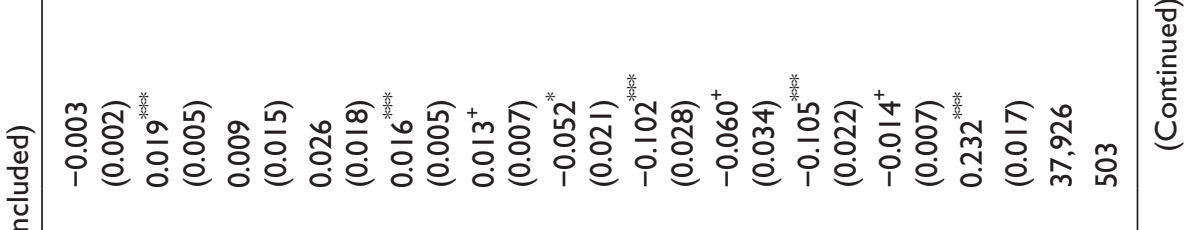

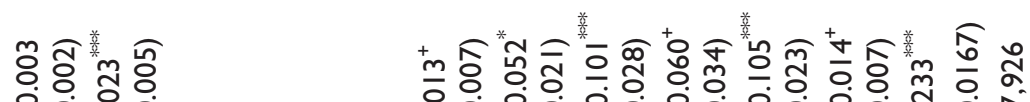

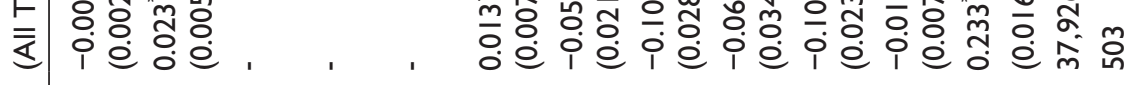

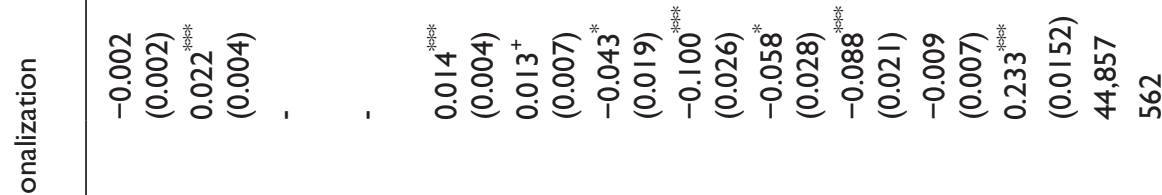

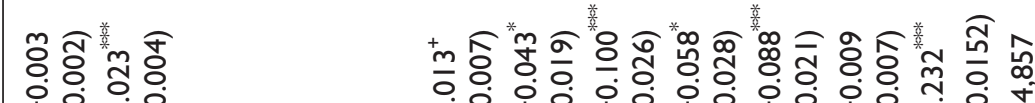

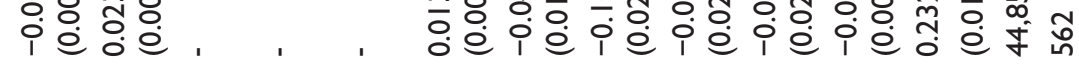

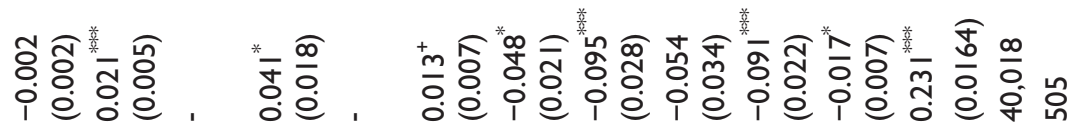

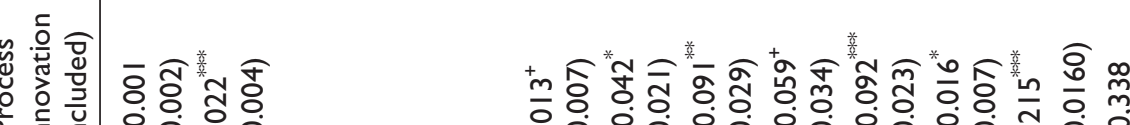

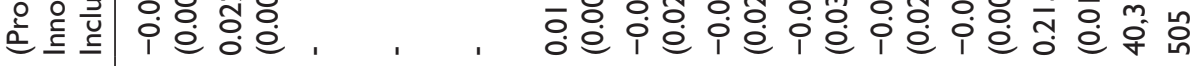

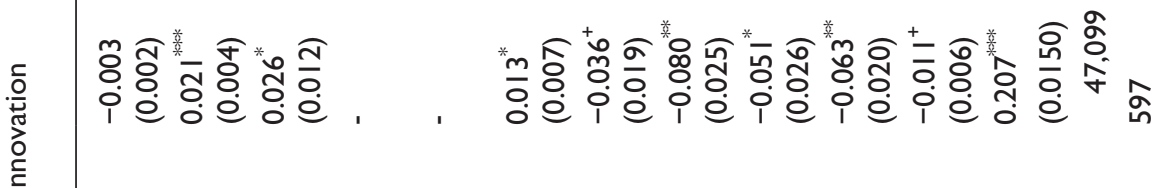

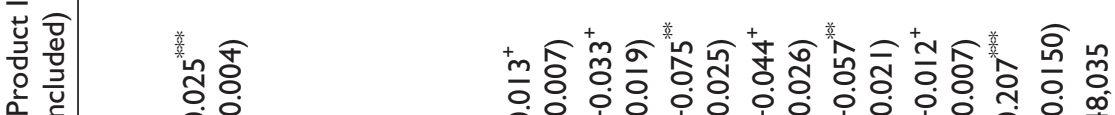

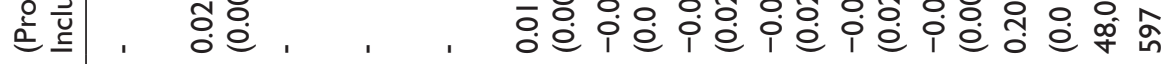

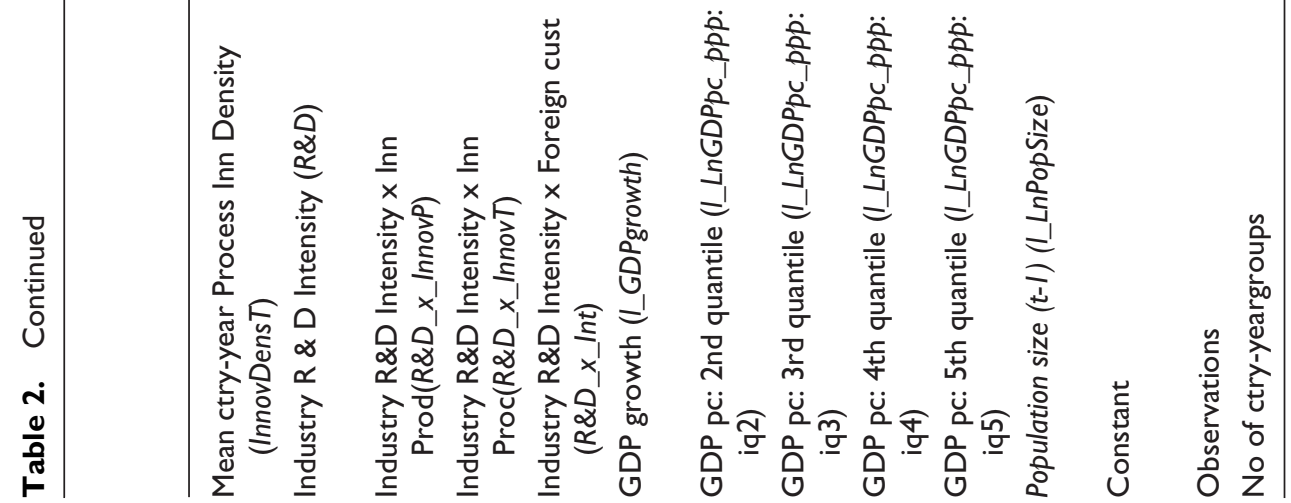




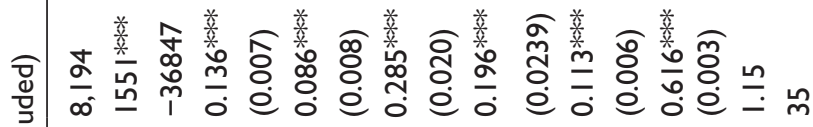

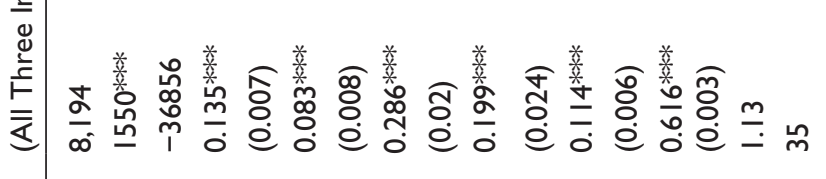

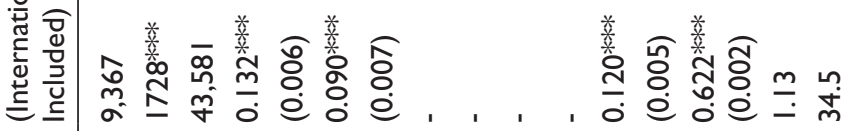

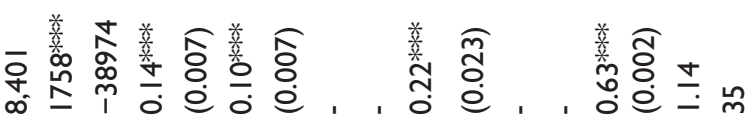

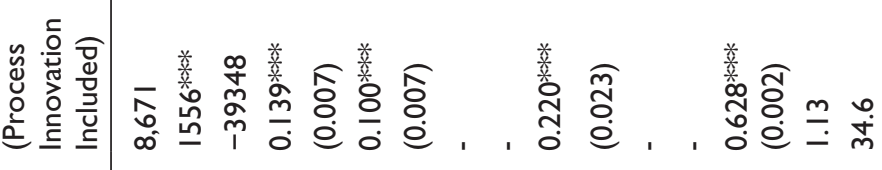

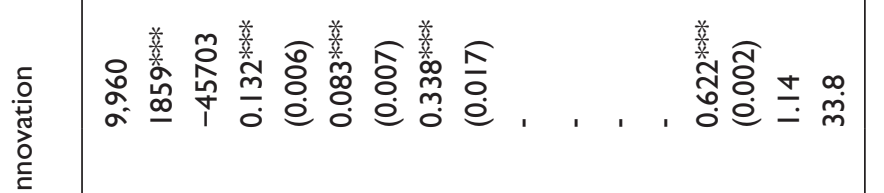




$$
\begin{aligned}
& E P G_{i j c}=\beta_{0}+\beta_{1} \text { LnL }_{i j c}+\beta_{2} \text { LnAge }_{i j c}+\beta_{3} \text { LnAge_sq }_{i j c}+\beta_{4} \text { Male }_{i j c}+ \\
& \beta_{5} \text { EducPost }_{i j c}+\beta_{6} \text { PortfolioE }_{i j c}+\beta_{7} \text { BusAngel }_{i j c}+\beta_{8} \text { Knows }_{i j c}+ \\
& \beta_{9} \text { InnovP }_{i j c}+\beta_{10} \text { InnovT }_{i j c}+\beta_{11} \text { Export }_{i j c}+\beta_{12} R \& D_{j c}+\beta_{13} \text { InnovDensP }_{j c} \\
& +\beta_{14} \text { InnovDensT }_{j c}+\beta_{15} l_{-} \text {GDPgrowth }_{c}+\beta_{16} i q 2_{c}+\beta_{17} i q 3_{c}+\beta_{18} i q 4_{c}+ \\
& \beta_{19} \text { iq }_{c}+\beta_{20} \text { I_LnPopSize }_{c}+u_{c}+\omega_{j c}+v_{i j} \text { InnovP }_{i j}+\varphi_{i j} \text { InnovT }_{i j}+ \\
& \mu_{i j} \text { Export }_{i j}+\epsilon_{i j c}
\end{aligned}
$$

where $E P G_{i j c}$ is our measure of entrepreneurial growth aspirations; and variables $\left\{L n L_{i j c}\right.$,

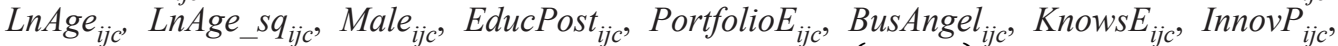
InnovT $_{i j c}$, Export $\left._{i j c}\right\}$ represent individual-level direct effects; $\left\{R \& D_{j c}\right\}$ represent direct industrylevel effect of R\&D intensity; $\left\{\right.$ InnovDens $P_{j c}$, InnovDens $\left.T_{j c}\right\}$ represent industry-country-year mean effects of innovation density by established firms (product and technology); and $\left\{l_{\text {_GDPgrowth }}, i q 2_{c}, i q 3_{c}, i q 4_{c}, i q 5_{c}, l_{-}\right.$LnPopSize $\left._{c}\right\}$ represent the lagged values of the macroeconomic controls. The combination of $\left\{u_{c}, \omega_{j c}, v_{i j}\right.$ Innov $P_{i j}, \phi_{i j}$ Innov $T_{i j}, \mu_{i j}$ Export $\left._{i j} \varepsilon_{i j c}\right\}$ is the random part of the equation, where $u_{c}$ are the country-year level residuals, $\omega_{j c}$ are the industry-level residuals; $v_{i j}$ Innov $P_{i j}, \phi_{i j}$ Innov $T_{i j}$ and $\mu_{i j}$ Exportare the random slopes of individual-level variables measuring entrepreneurs' innovation and internationalization respectively; and $\varepsilon_{i j c}$ represents individual-level residuals.

\section{Results}

Table 2 contains the results from using either innovative product (Model 1) or new process (Model 3) as our measures of entrepreneurs' strategic engagement in innovation, and early-stage internationalization (Model 5). These models can be used to test Hypotheses 1a-1c, and 2. The significance of the simultaneous effect is tested further in Model 7. As also already discussed, Models 2, 4 and 6 add interactive effects to test Hypotheses $3 a-3$ c. Model 8 in Table 2 tests all three pairwise interactions jointly. Figures $2-4$ plot the interaction effects graphically using $-/+1$ standard deviation range of values.

We find strong and largely consistent support for hypotheses H1a-H1c. The estimated coefficients on each of the three strategic choices, product and process innovation and internationalization, are positive and significant at the $1 \%$ level in all three specifications capturing their direct effects on entrepreneurial growth aspirations (Model 1, 3, and 5). Even in the more demanding specification, where all three strategic choices are entered jointly (Model 7, Table 2), they all retain their statistical significance.

We next consider the effect of knowledge-intensive industrial environment, proxied by R\&D intensity in industry on entrepreneurial growth aspirations. We confirm its direct effect on entrepreneurial growth aspirations in Models 1, 3, 5 and 7 in support of Hypothesis 2.

Hypothesis 3 postulates that knowledge intensity in the business environment might positively moderate the way that entrepreneur's strategic engagement in innovation and internationalization influences new venture predicted growth. As the results show (Models 2, 4, 6), such relationships are strong and positive for all three types of strategic engagement. Interestingly, the benefits from knowledge-intense environment in industry accrue both to entrepreneurs with engagement in product innovation, and those who do not engage in product innovation, but the effect is marginally stronger for the former as evidenced in Figure 2. The differential effect between process and nonprocess innovators increases at higher level of R\&D intensity $(+1$ st dev) (Figure 3). Similarly, the differential effect of knowledge intensity of the industry 


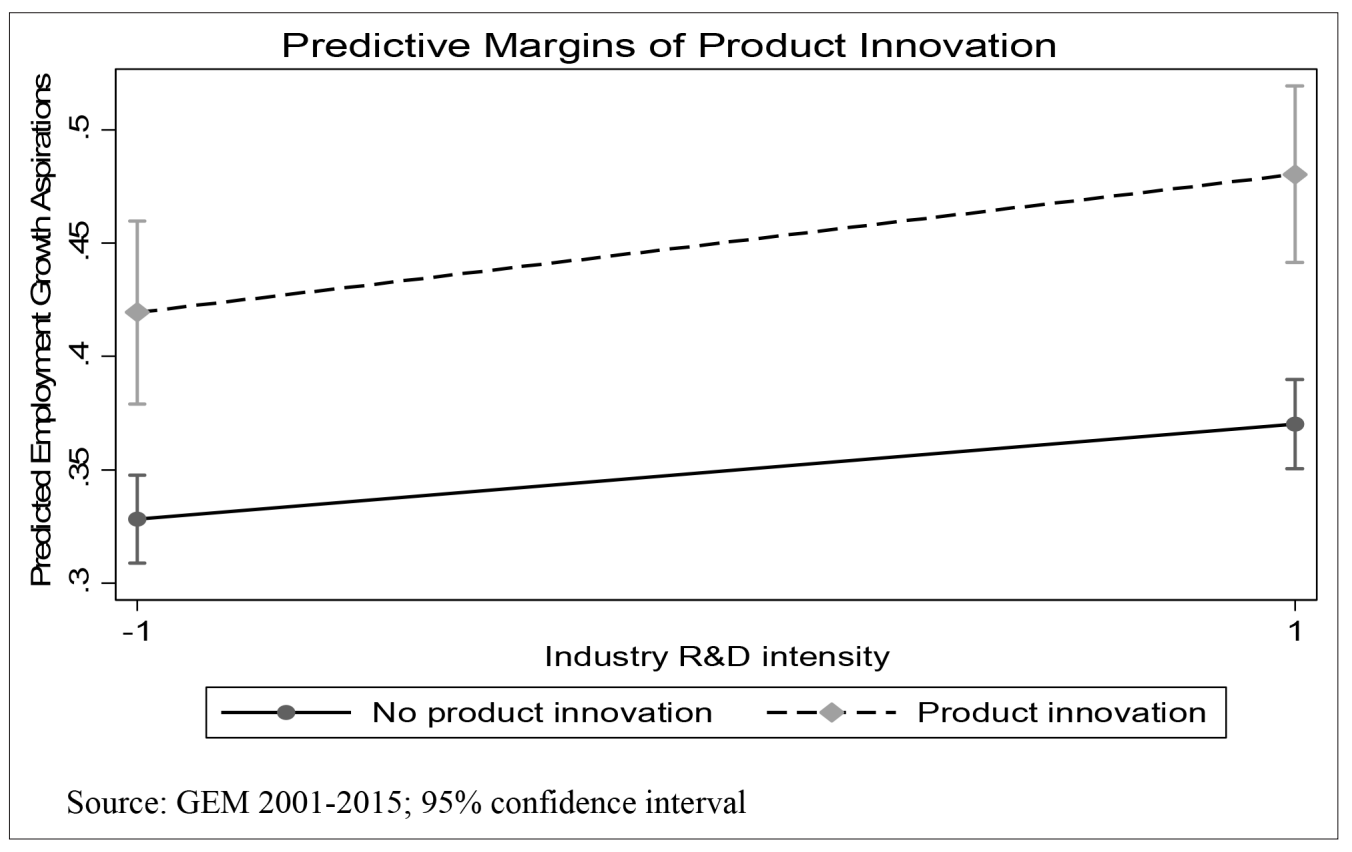

Figure 2. Plotting the two-way innovative Product-R\&D interaction results (based on Model 8, Table 2).

environment on internationalization increases with a relatively higher R\&D intensity of the industry (Figure 4).

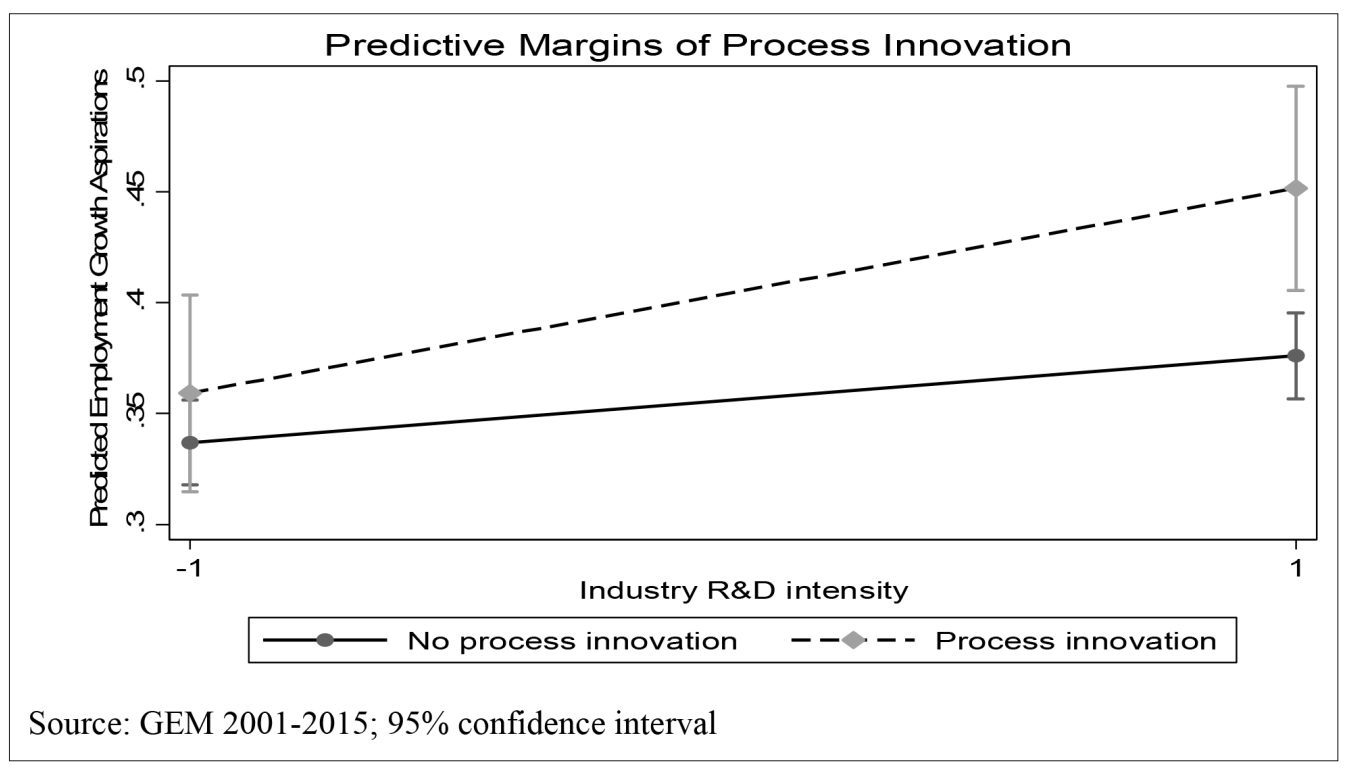

Figure 3. Plotting the two-way innovative Process-R\&D interaction results (based on Model 8, Table 2). 


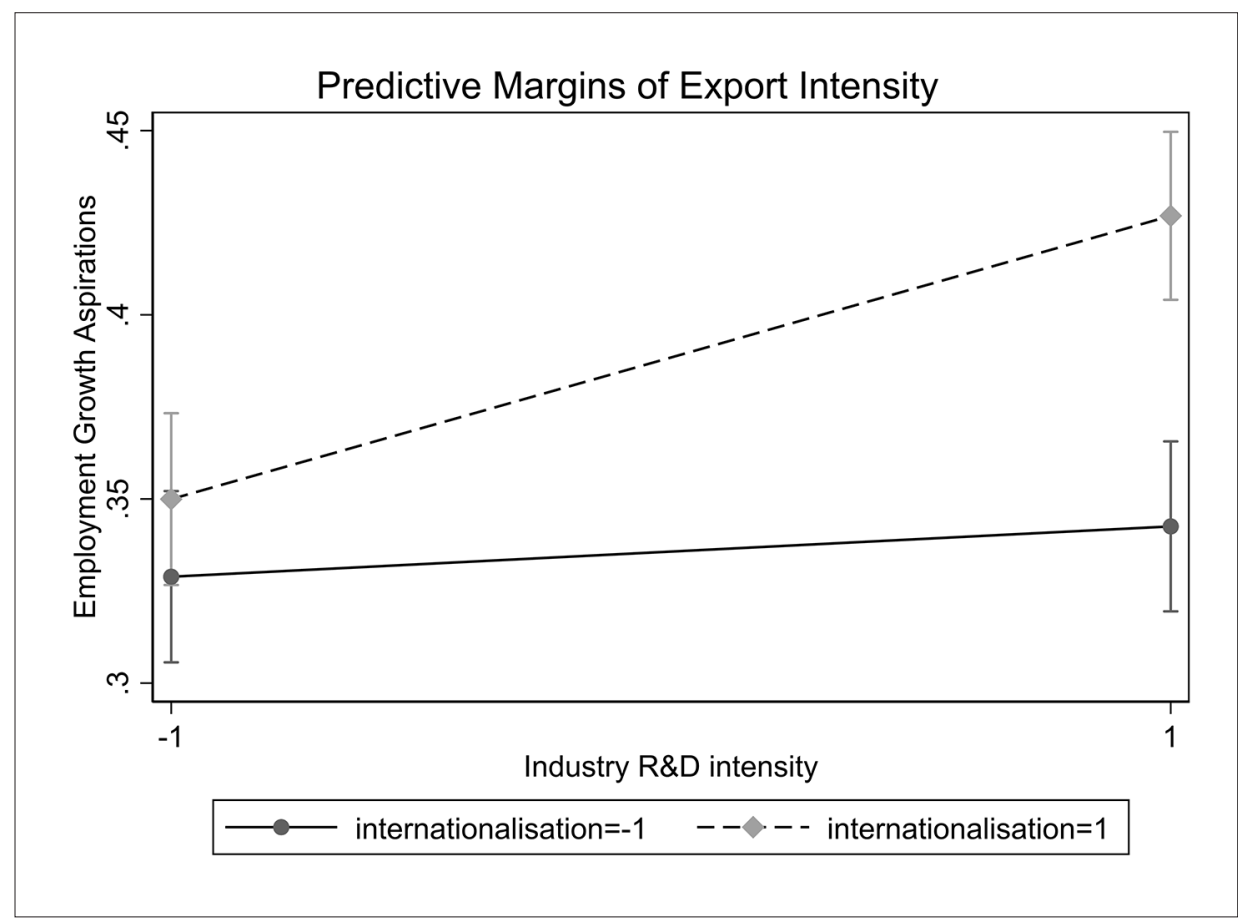

Figure 4. Plotting the two-way Internationalisation-R\&D interaction results (based on Model 8, Table 2).

\section{Robustness Checks}

Next, we consider several econometric problems, of which the two most important ones relate to: (1) the fact that the strategic activities and growth aspirations are only observed for the sample of actual entrepreneurs, and therefore could be subject to a potential selection bias; (2) potential reverse causality between an entrepreneur's engagement in innovation and exporting, and an entrepreneur's growth aspirations.

First, we address potential concerns about selection effects which arise because high growth aspirations entrepreneurs represent a subset of the people who have chosen to become entrepreneurs. We therefore model the entrepreneur's growth aspirations jointly with the entrepreneur's decision to enter entrepreneurship in the setting of the Heckman selection framework (Heckman, 1979). In the first stage, we utilize data on the rate of prevalence of informal finance to explain the decision to become an entrepreneur (for justification see: Estrin et al., 2013); the results of the first stage models are available on request. We go on to calculate the inverse Mills ratio and enter this as a control augmenting our equations. Second, we estimate jointly entrepreneurs' growth aspirations and each of the three strategic choices to address the reverse causality issue. We do this instrumentation one strategy at a time, using a pairwise approach to address a potential simultaneity bias between each of the strategies and entrepreneurial growth aspirations.

The inverse Mills ratio estimated in the first stage is found to be statistically significant, indicating the presence of selection bias, and so the results reported in Appendix Table A.II correct for this problem. The regressions reported in Appendix Table A.II are estimated simultaneously in the setting of the framework of seemingly unrelated regression equations (SURE), where equations are linked by their disturbances (Zellner, 1962). We implement the SURE to estimate an Instrumental Variable model using the Stata module $\mathrm{cmp}$ that allows for modeling conditional 
mixed processes (Roodman, 2011). To choose an instrumental variable for the three strategic choices, which does not affect the growth aspirations, we follow Muethel and Bond (2013) to argue that the "outgroup" trust variable is relevant to international business activity. We argue that it is also relevant for determining the innovation orientation of entrepreneurs if new products/services can be seen as the outcome of exchange of information with other entrepreneurs or strangers. We construct it as a scale variable based on three questions: "Trusting people of other nationality", "Trusting people of other religion", "Trusting people whom you met for first time", using the World Value Survey dataset (available from http://www.worldvaluessurvey.org/wvs. jsp). All three answers were reversed and combined into a scale with the higher value to denote more trust and were further aggregated to the country-year level. A scale was constructed based on the standardized values of these aggregates, with Cronbach's $\alpha$ reliability coefficient being equal to 0.93 . The second instrumental variable that we utilize to instrument strategic choices is national R\&D expenditures (as \% of GDP) obtained from the World Bank WDI dataset. We expect it to be positively associated with each of our three dimensions of strategic orientation, but not entrepreneurial growth aspirations, and we further confirm this empirically. We lag the $R \& D$ variable by 1 year $\left(l \_R \& D\right)$ and interact it with $R \& D$ intensity in an industry.

We also tested the robustness of our results by excluding those individuals who were reclassified from nascent to new business owners or were reported as belonging to both categories. ${ }^{6}$ The results remained robust; due to a space limit we do not report them here, but they are available upon request.

The self-reported variables derived from a single data source (in our case: GEM) may give rise to potential problem of common methods bias. However, we argue that our results do not suffer from this for the following reasons: (1) we test homogeneity of the scale of all four selfreported measures related to our dependent variable and the variables we use to test the hypotheses (innovativeness defined by technology and product, export intensity and growth aspirations), using Cronbach's $\alpha{ }^{7}$ The correlation between all four variables is not significant enough for them to form a uniform scaling; (2) we interact our key individual-level variables with an industry-level knowledge production intensity; that further eliminates potential risk of common methods variance bias through the interaction of two levels with data representing each of the levels coming from two different data sources (Engelen et al., 2014).

The results of the various robustness tests are reported in Appendix Table A.II. The table indicates that the results related to all three strategic choices hold after addressing the issues of both selection bias and potential reverse causality. However, the findings are marginally weaker for entrepreneurs engaged in process innovation and exporting ${ }^{8}$ in more industrial knowledgeintensive contexts(Appendix Figures A.1-A.3).

Turning to the control variables, the pattern conforms to expectations and findings elsewhere in the literature. First, we note that the initial level of employment is negatively and significantly related to entrepreneurial growth aspirations. Also, consistently across all specifications but for the product innovation regression testing the robustness to potential reverse causality, we find a positive effect for product innovation density in an industry on entrepreneurial growth aspirations. The presence of innovative products among established firms in an industry is likely to trigger a new entry to the market due to a demonstration effect and entrepreneurs adopting copycat ideas. In contrast, we find the inverse effect for process innovation density. The latter is likely to capture the investment spikes (Sakellaris, 2004), associated with a prospective gain in productivity of established firms. This threatens start-ups to be ousted from the market via competition. Interestingly, the effect only appears in robustness checks across all three specifications (Appendix Table AII).

Our results provide some evidence for a bell-shaped relationship between age and entrepreneurial growth aspirations (Appendix Table AII). Higher or postsecondary education, and being 
a male is also positively associated with growth aspirations, as is previous experience as a business angel. Being a portfolio entrepreneur has a significant positive effect on growth aspirations. The impact of knowing other entrepreneurs is always highly significant and positive. We find a weak positive effect of GDP growth on growth aspirations, as well as some effects from the level of economic development. Finally, we find positive and significant effect of population size for both product and process innovation, and growth, but negative for international orientation. The latter suggests that entrepreneurs in smaller-sized countries tend to become global from inception to overcome size constraints of local markets.

\section{Discussion}

We have developed a theoretical framework that we label Schumpeterian, because it seeks to understand the linkages between knowledge creation and acquisition and high growth aspirations of entrepreneurs. Entrepreneurs make strategic choices to engage in knowledge acquisition both via product and process innovation and via internationalization, and in so doing, they are also better able to benefit from the knowledge intensity of their sector. Emphasizing the strategic logic of opportunity formation at the early stage of operations (Alvarez \& Barney, 2007), we validate the importance of these different channels of knowledge acquisition. Extending expectancy theory, we posit that the resulting enhanced opportunities lead to higher growth aspirations. In particular, we hypothesize that the new innovations in products and in processes as well as the choice to seek foreign customers are important determinants of entrepreneurial growth aspirations. We suggest the transmission mechanism is entrepreneurial process based and operates through trial and error, and exposure to a knowledge-intensive business environment and to international markets, leading to the development of capabilities and resources. This strengthens the beliefs of entrepreneurs that their efforts will allow them to achieve their goals, raising the level of entrepreneurial aspirations; a process consistent with expectancy theory.

Our empirical work provides evidence consistent with our hypotheses. Thus, as predicted, the relationship between product innovation, process innovation, the range of foreign customers and growth aspirations is found to be positive and the finding is robust across a variety of specifications including addressing potential reverse causality. The relationship between product innovation and growth aspirations has a slightly greater impact than the other two strategic engagements, consistent with Stam and Wennberg (2009) and Kolvereid and Isaksen's (2017) results. This may also be in line with that branch of the literature that stresses the sequential aspects of product and process innovation, with product innovation appearing first and leading to the second, and therefore being of relatively higher importance (Hullova et al., 2016). If the second type of innovation amplifies the positive effect of the first, it also implies positive synergies when both are present.

Thus, we suggest that the most important aspect of the strategic choice to innovate by new ventures concerns new products rather than new technology. However, as hypothesized and supported by the results, the two strategic choices are synergic: entrepreneurs are more likely to have high growth aspirations when they engage in both types of innovation (product- and processrelated) jointly. This finding is consistent with the stress that Hullova et al. (2016) place on the value of complementarity. We add to the complementarity argument, illustrating the important role of exporting jointly with engagement in innovation in facilitating entrepreneurial growth aspirations (Love \& Roper, 2015; Love et al., 2010).

Furthermore, as highlighted by Wright et al. (2015), the role of the business environment in entrepreneurial growth is still not well understood. We follow the literature in proposing that a more knowledge intensive environment will naturally provide higher growth opportunities for entrepreneurs to exploit. Our empirical work goes on to explore the moderating effects of knowledge intensive industrial environments on the impact of strategies on growth aspirations. We find 
that the positive impact of the sectoral knowledge intensity on growth aspirations is amplified by entrepreneurs' engagement in all three types of strategies: product and process innovation, and internationalization. At the same time, the moderating effect of knowledge intensity is statistically weaker in the case of process innovation and this could be attributed to a steeper learning curve for entrepreneurs in making a productive use of new technology after its introduction (Sakellaris, 2004).

The findings suggest that opportunities within more knowledge-intense environments tend to accrue primarily to new ventures pursuing the strategic logic of engaging in product and process innovation activities and internationalization. A knowledge-intensive environment makes innovation-oriented ventures more open to the continuous flow of growth opportunities, enhancing expectancies of entrepreneurs and their aspirations.

Finally, we consider two interesting findings which are not our core results. First, consistently across almost all specifications, we find a positive effect of the variable representing the industrial density of product innovation. In contrast, we also find that the variable controlling for the industrial density of technology innovation is significant across all robustness specifications and is found to negatively affect the growth aspirations of entrepreneurs. It seems that new technologies developed by incumbent firms create some entry barriers that discourage young firms to grow. The negative effect of process innovation density may be attributed to the much steeper learning curve for start-ups (as opposed for established firms) to make productive use of new technology, probably because of the shortage of the resources needed, e.g. skilled labor or financial resources to absorb it, and in providing training to existing staff operating a new piece of equipment. In turn, high density of new product innovation may be a proxy of expanding consumer (or business clients) markets, which we are unable to measure directly, apart from the rate of GDP growth.

Second, being an owner-manager of another already established business consistently comes as the strongest and the most significant individual level effect across all the specifications. Thus, while we focus on learning-by-doing, there are also learning effects from experience, which are likely to play an important role for serial entrepreneurs, enhancing their aspirations. However, the difficulty in interpreting the positive effect of serial entrepreneurship on growth aspirations is that it could also be explained by better resource endowment, for example these entrepreneurs may be in a good position to use the financial resources the already accumulated to expand (Mickiewicz et al., 2017). Finally, there may be another selection mechanism at work: given opportunity cost of time that could be spent on managing the existing older venture, these entrepreneurs only undertake new ventures with significant growth potential.

\section{Conclusions}

The commonly used measures of entrepreneurship, including self-employment and the GEM indicators of nascent and young entrepreneurial activity, only imperfectly capture the elements of new ventures critical to development, especially those of Schumpeterian nature. Many entrepreneurial firms are created to provide employment for their founders and perhaps to their families (Stam et al., 2012). In emerging markets, such entry may take the form of "necessity" entrepreneurship. In developed economies, to this, one must add the creation of small firms for lifestyle reasons, including increased employment flexibility or to attain other personal goals (Stephan et al., 2015). Furthermore, in developed economies entrepreneurial skills may also be effectively utilized within large, efficient business firms (Stam, 2013). Thus, the measures of entrepreneurial entry are noisy as indicators of economic dynamism.

Responding to this, we focus research attention on a subset of new ventures, namely on those which have survived the critical creation phase, and which are now contemplating growth. Our 
dependent variable is growth intentions, a proxy of which is usually labeled as growth expectations or aspirations (Stam et al., 2012), which fits into framework of expectancy theory. We build upon the latter, and relate entrepreneurs' ambitions not only to the characteristics of the entrepreneur, as has been central in much of the expectancy theory literature, but to critical elements defining their strategy and to the sectoral context in which they operate. We focus on the entrepreneur's strategic logic of opportunity, a concept, which we broaden by including product and process innovation, and internationalization. Building on Alvarez and Barney (2007) we link such strategic behavior to learning and to creation of new opportunities by entrepreneurs. At the sectoral level, we concentrate on business opportunities resulting from knowledge generated by others (R\&D intensity in industry), and its amplifying effects on the relationship between strategic behavior and growth aspirations.

We propose that a multidirectional strategic engagement of entrepreneurs with respect to innovation and internationalization will lead to higher entrepreneurial growth aspirations, and further confirm this empirically. We also find that the entrepreneurs with a strategic focus on process innovation and acquiring foreign customers are likely to benefit most from more knowledge-intensive industrial environments.

Our study has important ramifications for researchers and policy makers as well as entrepreneurs. For researchers, it suggests that the definition of types of entrepreneurial activity in theoretical and empirical work should be more finely grained, so that the distinctions can be drawn between new firms created to provide employment for their founder (and their friends and family), and new ventures, which have the objective of growth. Within the latter category, we propose to focus on a further important subset of Schumpeterian entrepreneurs, for whom, unlike for Kirzner's (1973) arbitrageurs, growth aspirations result from expanding opportunity set generated by knowledge augmenting activities.

Overall, our study is an early step in identifying linkages between innovation, entrepreneurship and strategy theories, by articulating the Schumpeterian mechanism of how entrepreneurs' strategic decisions to innovate and to win foreign customers are likely to lead to higher growth ambitions. These insights allow us to bridge the gap between the innovation, strategic management and entrepreneurship literatures by articulating the importance of knowledge acquisition, and of identifying strategies for entrepreneurs to gain from opportunity discovery and creation. This line of enquiry may in time lead to a better understanding of the micro-foundations of Schumpeter (1934 ) proposition that (ambitious) entrepreneurship must be closely aligned with innovation. We believe that the innovation and entrepreneurship literatures have been drifting apart, and it may be a good time to reconnect them within the Schumpeterian tradition.

At the same time, a limitation we share with much of other research on innovation and entrepreneurship is that we consider the entrepreneur within a single venture. From this perspective, entrepreneurial success may appear less likely than it is. Levie et al. (2011) offer a succinct analysis of evidence, questioning the long-established claim that entrepreneurial failure is common (see Geroski, 1995; Headd, 2003). The discontinuation rates of new businesses are lower than typically claimed, and many discontinuations are not failures. This is where more research is needed, in order to focus on the entrepreneur (or on the entrepreneurial team) as the carrier of acquired knowledge; the positive effect on entrepreneurial aspirations may be carried over to the next venture. Thus, while we focus on learning-by-doing (by adopting innovation and internationalization strategies) during the early stage of the new venture, consistent with the Alvarez and Barney (2007) perspective on "creative entrepreneurship", an equally important question is how entrepreneurs benefit from their experience in earlier ventures, both unsuccessful and successful. A very significant coefficient in our own results on ownership of other (established) business(es) is a clear indication that these effects are important. 
Another clear limitation is that we lack a time dimension in our study. In particular, we take internationalization and innovation as both occurring in the early stage of the new venture, but we cannot identify the actual sequence. As argued by Love et al. (2010), firms "generate knowledge inputs for innovation through forward linkages to customers. This may reflect either formal or informal knowledge sharing, but provides an indication of the potential importance of, say, knowledge of customers' preferences in shaping firms' innovation success" (Ibid.: 986). In addition, Love et al. (2010) posit that competitors represent another source of innovation effects which act to enhance learning. We see these arguments as applying to entrepreneurs with a wider base of foreign customers in particular. Likewise, exposure to foreign markets implies more exposure to competitors. This is why exporting may be a source of knowledge that leads to innovative activities. However, such dynamic, learning effects are impossible to identify with our data.

Our study also has implications beyond the academic community. The strategic orientation of new ventures with respect to innovation can be influenced by the flow of information at the industrial level made available by governmental and nongovernmental support agencies. This supplements previous findings about geographically based agglomeration effects. Because aspects of strategic orientation and environmental knowledge diffusion are mutually reinforcing, this suggests that the returns to any particular policy supporting each of these elements will be greater: a comprehensive policy will work best.

As regards entrepreneurs, our study suggests that to remain competitive in a dynamic market environment, entrepreneurs should not assume that a one-off experience of being engaged in a high-impact activity, such as innovation or exporting, is sufficient. Rather, entrepreneurs must translate their experience into articulated heuristics that produces patterning of high-performing organizational activity, including, for example, the ways to innovate or export that are central to the development of growth capabilities. Such activities will be based on the search for competitive advantage which, through the generation of new products, processes, and entering new markets, can lead to wealth creation sustainable over time.

\section{Declaration of Conflicting Interests}

The author(s) declared no potential conflicts of interest with respect to the research, authorship, and/or publication of this article.

\section{Funding}

The author(s) received no financial support for the research, authorship, and/or publication of this article.

\section{ORCID IDs}

Saul Estrin (D) https://orcid.org/0000-0002-3447-8593

Tomasz Mickiewicz (iD https://orcid.org/0000-0001-5261-5662

\section{Notes}

1. Employment not just employees: we combine the number of owner-managers reported by entrepreneurs with the number of employees. We are grateful to an anonymous referee for suggesting to us how to improve the quality of the measure through this correction.

2. We are grateful to an anonymous referee for constructive suggestions on this and on other aspects of methodology. The GEM variable, focused on customers, fits the focus on learning much better than a traditional accounting variable related to proportion of sales. On the other hand, it would be very good to know the number of countries to which a new venture exports. 
3. It might have been better to use country-sectoral rates, but unfortunately these are not available for our sample of countries.

4. We thank an anonymous referee for suggesting this control variable.

5. The United Nations ISIC Rev 3.1 and 4 correspondence tables can be accessed from the following URL: https://www.unescwa.org/sites/www.unescwa.org/files/events/files/event_detail_id_1596_revison4revison31en.pdf.

6. We thank an anonymous referee for suggesting this robustness test.

7. It would not be appropriate to combine the two measures of innovation into a single scale because Cronbach's $\alpha$ was low (0.19), and so we present the results for each both separately and when they enter the regression jointly alongside each other.

8. In our internationalization model (model 11, Table A.II), the two instruments, namely outgroup trust and $R \& D$ expenditure at a country level, become marginally insignificant in explaining internationalization of entrepreneurs. We further perform Durbin-Wu-Hausman test for endogeneity, and as part of this procedure, we test the validity of our instruments in exporting equation, using Hansen's test for overidentifying restrictions. Hansen's J chi2(3) $=3.87873, p=0.2749$, which validates our choice of instruments.

\section{Supplemental Material}

Supplemental material for this article is available online.

\section{References}

Agarwal, R., Audretsch, D., \& Sarkar, M. B. (2007). The process of creative construction: Knowledge spillovers, entrepreneurship, and economic growth. Strategic Entrepreneurship Journal, 1(3-4), 263-286. https://doi.org/10.1002/sej.36

Allison, P. (2012). When can you safely ignore multicollinearity. In Statistical Horizons (5 (1)). https:// statisticalhorizons.com/multicollinearity.

Alvarez, S. A., \& Barney, J. B. (2007). Discovery and creation: Alternative theories of entrepreneurial action. Strategic Entrepreneurship Journal, 1(1-2), 11-26. https://doi.org/10.1002/sej.4

Arrighetti, A., \& Vivarelli, M. (1999). The role of innovation in the post entry performance of new small firms: Evidence from Italy. Southern Economic Journal, 65(4), 927-939. https://doi.org/10.2307/ 1061285

Audretsch, D. B. (1995). Innovation and industry evolution. MIT Press.

Audretsch, D. B., \& Keilbach, M. (2007). The theory of knowledge spillover entrepreneurship. Journal of Management Studies, 44(7), 1242-1254. https://doi.org/10.1111/j.1467-6486.2007.00722.x

Audretsch, D. B., \& Keilbach, M. (2008). Resolving the knowledge paradox: Knowledge-spillover entrepreneurship and economic growth. Research Policy, 37(10), 1697-1705. https://doi.org/10.1016/j. respol.2008.08.008

Autio, E. (2005). Global entrepreneurship monitor: 2005 report on high-expectation entrepreneurship. London Business School and Babson College.

Autio, E., \& Acs, Z. (2010). Intellectual property protection and the formation of entrepreneurial growth aspirations. Strategic Entrepreneurship Journal, 4(3), 234-251. https://doi.org/10.1002/sej.93

Autio, E., Kenney, M., Mustar, P., Siegel, D., \& Wright, M. (2014). Entrepreneurial innovation: The importance of context. Research Policy, 43(7), 1097-1108. https://doi.org/10.1016/j.respol.2014.01.015

Autio, E., \& Rannikko, H. (2016). Retaining winners: Can policy boost high-growth entrepreneurship? Research Policy, 45(1), 42-55. https://doi.org/10.1016/j.respol.2015.06.002

Baumol, W. J. (2010). The microtheory of innovative entrepreneurship. Princeton University Press.

Baumol, W. J., Litan, R. E., \& Schramm, C. J. (2007). Good capitalism, bad capitalism, and the economics of growth and prosperity. Yale University Press. https://doi.org/10.2139/ssrn.985843 
Becker, S. O., \& Egger, P. H. (2013). Endogenous product versus process innovation and a firm's propensity to export. Empirical Economics, 44(1), 329-354. https://doi.org/10.1007/s00181-009-0322-6

Bingham, C. B., \& Eisenhardt, K. M. (2008). Position, leverage and opportunity: A typology of strategic logics linking resources with competitive advantage. Managerial and Decision Economics, 29(2-3), 241-256. https://doi.org/10.1002/mde.1386

Bingham, C., Eisenhardt, K., \& Furr, N. (2007). What makes a process a capability? Heuristics, strategy and effective capture of opportunities. Strategic Management Journal, 1(1-2), 27-47.

Bingham, C., Eisenhardt, K., \& Furr, N. (2011). Which strategy when? MIT Sloan Management Review, 53(1), 71-78.

Bruneel, J., Yli-Renko, H., \& Clarysse, B. (2010). Learning from experience and learning from others: How congenital and interorganizational learning substitute for experiential learning in young firm internationalization. Strategic Entrepreneurship Journal, 4(2), 164-182. https://doi.org/10.1002/sej. 89

Capelleras, J. L., Martin-Sanchez, V., Rialp, J., \& Shleha, W. (2018). Entrepreneurs' export orientation and growth aspirations: The moderating role of individual human capital. In G. Bosio, T. Minola, F. Origo, \& S. Tomelleri (Eds.), Rethinking entrepreneurial human capital (pp. 63-87). Springer.

Colombelli, A., Krafft, J., \& Vivarelli, M. (2016). To be born is not enough: The key role of innovative startups. Small Business Economics, 47(2), 277-291. https://doi.org/10.1007/s11187-016-9716-y

Engelen, A., Kube, H., Schmidt, S., \& Flatten, T. C. (2014). Entrepreneurial orientation in turbulent environments: The moderating role of absorptive capacity. Research Policy, 43(8), 1353-1369. https://doi. org/10.1016/j.respol.2014.03.002

Estrin, S., Korosteleva, J., \& Mickiewicz, T. (2013). Which institutions encourage entrepreneurial growth aspirations? Journal of Business Venturing, 28(4), 564-580. https://doi.org/10.1016/j.jbusvent.2012. 05.001

Estrin, S., \& Mickiewicz, T. (2011). Institutions and female entrepreneurship. Small Business Economics, 37(4), 397-415. https://doi.org/10.1007/s11187-011-9373-0

Estrin, S., Mickiewicz, T., Stephan, U., \& Wright, M. (2019). Entrepreneurship in emerging markets. In R. Grosse \& K. Meyer (Eds.), The oxford handbook of management in emerging markets (pp. $457-$ 494). Oxford University Press.

Galindo-Rueda, F., \& Verger, F. (2016). Taxonomy of economic activities based on R\&D intensity, OECD science, technology and industry Working Papers, 2016/04. OECD Publishing.

Geroski, P. A. (1995). What do we know about entry? International Journal of Industrial Organization, 13(4), 421-440. https://doi.org/10.1016/0167-7187(95)00498-X

Glaeser, E. L., Kallal, H. D., Scheinkman, J. A., \& Shleifer, A. (1992). Growth in cities. Journal of Political Economy, 100(6), 1126-1152. https://doi.org/10.1086/261856

Headd, B. (2003). Redefining business success: Distinguishing between closure and failure. Small Business Economics, 21(1), 51-61. https://doi.org/10.1023/A:1024433630958

Heckman, J. J. (1979). Sample selection bias as a specification error. Econometrica, 47(1), 153-161. https:// doi.org/10.2307/1912352

Hullova, D., Trott, P., \& Simms, C. D. (2016). Uncovering the reciprocal complementarity between product and process innovation. Research Policy, 45(5), 929-940. https://doi.org/10.1016/j.respol.2016.01.012

Hurst, E., \& Pugsley, B. (2011). What do small businesses do? Brookings Papers on Economic Activity, 43(2), 73-142.

Ketchen, D. J., Ireland, R. D., \& Snow, C. C. (2007). Strategic entrepreneurship, collaborative innovation, and wealth creation. Strategic Entrepreneurship Journal, 1(3-4), 371-385. https://doi.org/10.1002/sej. 20

Kirzner, I. (1973). Competition and entrepreneurship. University of Chicago Press.

Koellinger, P. D., \& Roy Thurik, A. (2012). Entrepreneurship and the business cycle. Review of Economics and Statistics, 94(4), 1143-1156. https://doi.org/10.1162/REST_a_00224 
Kolvereid, L., \& Isaksen, E. J. (2017). Expectations and achievements in new firms. Journal of Small Business and Enterprise Development, 24(3), 649-668. https://doi.org/10.1108/JSBED-11-2016-0189

Levie, J., \& Autio, E. (2011). Regulatory burden, rule of law, and entry of strategic entrepreneurs: An international panel study. Journal of Management Studies, 48(6), 1392-1419. https://doi.org/10.1111/ j.1467-6486.2010.01006.x

Levie, J., \& Autio, E. (2013). Growth and growth intentions. White paper, 1, 159-183.

Levie, J., Don, G., \& Leleux, B. (2011). The new business mortality myth. In K. Hindle \& K. Klyver (Eds.), Handbook of research on new venture creation (pp. 194-215). Edward Elgar.

Love, J. H., \& Roper, S. (2015). SME innovation, exporting and growth: A review of existing evidence. International Small Business Journal: Researching Entrepreneurship, 33(1), 28-48. https://doi.org/10. $1177 / 0266242614550190$

Love, J. H., Roper, S., \& Hewitt-Dundas, N. (2010). Service innovation, embeddedness and business performance: Evidence from Northern Ireland. Regional Studies, 44(8), 983-1004. https://doi.org/10. 1080/00343400903401568

Manolova, T. S., Carter, N. M., Manev, I. M., \& Gyoshev, B. S. (2007). The differential effect of men and women entrepreneurs' human capital and networking on growth expectancies in Bulgaria. Entrepreneurship Theory and Practice, 31(3), 407-426. https://doi.org/10.1111/j.1540-6520.2007. 00180.x

McKelvie, A., Brattström, A., \& Wennberg, K. (2017). How young firms achieve growth: Reconciling the roles of growth motivation and innovative activities. Small Business Economics, 49(2), 273-293. https://doi.org/10.1007/s11187-017-9847-9

Meyer, K. E., \& Sinani, E. (2009). When and where does foreign direct investment generate positive spillovers? A meta-analysis. Journal of International Business Studies, 40(7), 1075-1094. https://doi.org/ 10.1057/jibs.2008.111

Mickiewicz, T., Nyakudya, F. W., Theodorakopoulos, N., \& Hart, M. (2017). Resource endowment and opportunity cost effects along the stages of entrepreneurship. Small Business Economics, 48(4), 953 976. https://doi.org/10.1007/s11187-016-9806-x

Minniti, M., Arenius, P., \& Langowitz, N. (2005). Global entrepreneurship monitor: 2004 report on women and entrepreneurship. Centre for Women's Leadership at Babson College. London Business School.

Mthanti, T., \& Ojah, K. (2017). Entrepreneurial orientation (EO): Measurement and policy implications of entrepreneurship at the macroeconomic level. Research Policy, 46(4), 724-739. https://doi.org/10. 1016/j.respol.2017.01.012

Muethel, M., \& Bond, M. H. (2013). National context and individual employees' trust of the out-group: The role of societal trust. Journal of International Business Studies, 44(4), 312-333. https://doi.org/ 10.1057/jibs.2013.9

Parker, S. C. (2018). The economics of entrepreneurship. Cambridge University Press.

Rabe-Hesketh, S., Skrondal, A., \& Pickles, A. (2005). Maximum likelihood estimation of limited and discrete dependent variable models with nested random effects. Journal of Econometrics, 128(2), 301323. https://doi.org/10.1016/j.jeconom.2004.08.017

Roodman, D. (2011). Fitting fully observed recursive mixed-process models with CMP. The Stata Journal: Promoting Communications on Statistics and Stata, 11(2), 159-206. https://doi.org/10.1177/ $1536867 X 1101100202$

Sakellaris, P. (2004). Patterns of plant adjustment. Journal of Monetary Economics, 51(2), 425-450. https:// doi.org/10.1016/j.jmoneco.2003.03.002

Schumpeter, J. (1934[2008]). The theory of economic development. Transaction Publishers.

Schwens, C., Zapkau, F. B., Bierwerth, M., Isidor, R., Knight, G., \& Kabst, R. (2018). International entrepreneurship: A meta-analysis on the internationalization and performance relationship. Entrepreneurship Theory and Practice, 42(5), 734-768. https://doi.org/10.1177/1042258718795346 
Schøtt, T., \& Jensen, K. W. (2016). Firms' innovation benefiting from networking and institutional support: A global analysis of national and firm effects. Research Policy, 45(6), 1233-1246. https://doi.org/10. 1016/j.respol.2016.03.006

Sirén, C. A., Kohtamäki, M., \& Kuckertz, A. (2012). Exploration and exploitation strategies, profit performance, and the mediating role of strategic learning: Escaping the exploitation trap. Strategic Entrepreneurship Journal, 6(1), 18-41. https://doi.org/10.1002/sej.1126

Stam, E. (2013). Knowledge and entrepreneurial employees: A country-level analysis. Small Business Economics, 41(4), 887-898. https://doi.org/10.1007/s11187-013-9511-y

Stam, E., Bosma, N., Van Witteloostuijn, A., De Jong, J., Bogaert, S., Edwards, N., \& Jaspers, F. (2012). Ambitious entrepreneurship. A review of the academic literature and new directions for public policy. Advisory Council for Science and Technology Policy (AWT) and the Flemish Council for Science and Innovation, .

Stam, E., \& Wennberg, K. (2009). The roles of R\&D in new firm growth. Small Business Economics, 33(1), 77-89.

Stephan, U., Hart, M., Mickiewicz, T., \& Drews, C. C. (2015). Understanding motivations for entrepreneurship. Department for Business Education and Skills.

Vroom, V. H. (1964). Work and motivation. Wiley.

Welter, F. (2011). Contextualizing entrepreneurship - conceptual challenges and ways forward. Entrepreneurship Theory and Practice, 35(1), 165-184. https://doi.org/10.1111/j.1540-6520.2010. 00427.x

Wiggins, R. R., \& Ruefli, T. W. (2005). Schumpeter's ghost: Is hypercompetition making the best of times shorter? Strategic Management Journal, 26(10), 887-911. https://doi.org/10.1002/smj.492

Wiklund, J., Davidsson, P., \& Delmar, F. (2003). What do they think and feel about growth? An expectancy-value approach to small business managers' attitudes toward growth. Entrepreneurship Theory and Practice, 27(3), 247-270. https://doi.org/10.1111/1540-8520.t01-1-00003

Wiklund, J., \& Shepherd, D. (2003). Aspiring for, and achieving growth: The moderating role of resources and opportunities. Journal of Management Studies, 40(8), 1919-1941. https://doi.org/10.1046/j.14676486.2003.00406.x

Wooldridge, J. M. (2015). Introductory econometrics: A modern approach (5th ed.). South Western Cengage Learning.

Wright, M., Filatotchev, I., Hoskisson, R. E., \& Peng, M. W. (2005). Strategy research in emerging economies: Challenging the conventional wisdom. Journal of Management Studies, 42(1), 1-33. https://doi. org/10.1111/j.1467-6486.2005.00487.x

Wright, M., Roper, S., Hart, M., \& Carter, S. (2015). Joining the dots: Building the evidence base for SME growth policy. International Small Business Journal, 33(1), 3-11. https://doi.org/10.1177/ 0266242614558316

Zellner, A. (1962). An efficient method of estimating seemingly unrelated regressions and tests for aggregation bias. Journal of the American Statistical Association, 57(298), 348-368. https://doi.org/10.1080/ 01621459.1962 .10480664

\section{Author Biographies}

Saul Estrin is an Emeritus Professor of Managerial Economics and Strategy and the founding Head of the Department of Management at London School of Economics (LSE), UK. At LSE he is affiliated with the Centre for Economic Performance and was the Research Director of the Entrepreneurship Institute. Saul's research has long focused on the micro-economics of comparative economic systems. In recent years, he has concentrated on international business strategy issues and entrepreneurship. 
Julia Korosteleva is Associate Professor in Business Economics at University College London (UCL), UK. She holds a PhD in Economics from the University of Bath, UK. At UCL Dr Korosteleva is affiliated with the Centre for Comparative Studies of Emerging Economies. Julia's research interests lie in the field of entrepreneurship, start-up finance, regional economics, and financial development.

Tomasz Mickiewicz is 50th Anniversary Professor at Aston Business School, Aston University, Birmingham, and Honorary Research Fellow, University College London, UK. Tomasz's research interests lie in the field of comparative entrepreneurship, international business, institutional economics, regional economics, high growth aspiration entrepreneurship, and informal economy. 